\title{
Altered Level of Soluble fms-like Tyrosine Kinase 1 (sFlt1) and Hypoxia Inducible Factor-1 $\alpha$ (HIF-1 $\alpha$ ) in Normotensive Pregnancy and Preeclampsia
}

\author{
John Wantania ${ }^{1,2,}$, Syakib Bakri1 ${ }^{1,3}$, Karel Pandelaki², Maisuri Chalid ${ }^{1,3}$ \\ ${ }^{1}$ Postgraduate Program in Biomedics, Hasanuddin University, Jl. Perintis Kemerdekaan Km.10, Makassar, Indonesia \\ ${ }^{2}$ Faculty of Medicine, Sam Ratulangi University, Jl. Kampus Unsrat, Manado, Indonesia \\ ${ }^{3}$ Faculty of Medicine, Hasanuddin University, Jl.Perintis Kemerdekaan Km.10, Makassar, Indonesia \\ *Corresponding author. E-mail: john_w_md@yahoo.com
}

\section{Abstract}

$\mathrm{B}$

ACKGROUND: Preeclampsia is still a significant problem worldwide. Of the many suggested mechanisms of its pathogenesis, the latest one is the balance of angiogenic factor and its relationship with hypoxia factors. The objective of this study was to observe changes or dynamic process of soluble fms-like tyrosine kinase 1 (sFlt1) as anti-angiogenic factor and hypoxiainducible factor 1-alpha (HIF-1 $\alpha$ ) as hypoxia marker in normotensive pregnancy and preeclampsia in mid-term and full-term pregnancies.

METHODS: A cohort study was conducted on 36 normotensive subjects, first examination was conducted at 20-28 weeks of gestation. Then second examination was conducted at the time of preeclampsia diagnosed or full-term pregnancy. Preeclampsia was characterized by hypertension of systolic blood pressure $\geq 140 \mathrm{mmHg}$, diastolic blood pressure $\geq 90 \mathrm{mmHg}$, with two readings separated in 4-6 hours period, and/or proteinuria with urine dipstick of $\geq 1+$ or $\geq 300 \mathrm{mg}$ per 24 hours. Examinations of sFlt- 1 and HIF$1 \alpha$ were done by enzyme-linked immunosorbent assay method. Statistical analysis was done using a significance level of $p<0.05$.

RESULTS: Concentration of sFlt-1 was elevated in normotensive pregnancy and preeclampsia. Higher sFlt1 concentration elevation was seen in preeclamptic group comparing to normotensive group, although not significant. This finding was related to the fact that investigated subjects were mostly developing mild preeclampsia merely. Comparing to normotensive group, preeclamptic group had higher HIF-1 $\alpha$ concentration-per-week elevation, but not significant. There was a positive correlation between

\section{Abstrak}

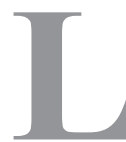

ATAR BELAKANG: Preeklamsia masih merupakan masalah di dunia yang signifikan. Dari beberapa mekanisme patogenesis yang disarankan, keseimbangan faktor angiogenik dan hubungannya dengan faktor hipoksia merupakan mekanisme terbaru. Tujuan penelitian ini untuk melihat perubahan atau proses dinamis pada soluble fms-like tyrosine kinase 1 (sFlt1) sebagai faktor anti-angiogenik dan hypoxia-inducible factor 1-alpha (HIF-1 $\alpha$ ) sebagai penanda hipoksia pada kehamilan normotensif dan preeklamsia pada waktu pertengahan dan akhir kehamilan.

METODE: Studi kohort dilakukan pada 36 subyek normotensi, pemeriksaan pertama dilakukan pada usia kehamilan 20-28 minggu. Kemudian pemeriksaan kedua dilakukan pada saat didiagnosa preeklamsia atau saat akhir kehamilan. Preeklamsia ditandai dengan hipertensi dengan tekanan darah sistolik $\geq 140 \mathrm{mmHg}$ dan/atau diastolik $\geq 90$ mmHg, dengan pembacaan 2 kali pada rentang waktu 4-6 jam; proteinuria dengan dipstik urin $\geq 1+$ atau $\geq 300 \mathrm{mg}$ per 24 jam. Pemeriksaan sFlt-1 dan HIF-1 $\alpha$ dilakukan dengan metode enzyme-linked immunosorbent assay. Analisa statistik menggunakan tingkat signifikan $p<0,05$.

HASIL: konsentrasi sFlt-1 mengalami kenaikan pada kehamilan preeklamsia dan normotensi. Peningkatan konsentrasi sFlt-1 yang lebih tinggi terlihat pada grup preeklamsia, dibandingkan grup normotensif, meskipun tidak signifikan. Temuan ini berkaitan dengan fakta bahwa pada subyek yang diteliti, kebanyakan hanya mengalami preeklamsia ringan. Dibandingkan grup normotensif, grup preeklamsia memiliki peningkatan konsentrasi-per-minggu HIF-1 $\alpha$ lebih tinggi, namun tidak signifikan. Terdapat 
concentrations of sFlt-1 and HIF-1 $\alpha$, but not significant.

CONCLUSION: sFlt-1 concentration elevation was correlated with preeclampsia. Therefore comparing to averages, changes of sFlt-1 concentrations were more important. Concentrations of HIF-1 $\alpha$ and sFlt-1 were positively correlated.

KEYWORDS: sFlt-1, HIF-1 $\alpha$, preeclampsia, normotension korelasi positif pada konsentrasi HIF-1 $\alpha$ dan sFlt-1, namun tidak signifikan.

KESIMPULAN: Peningkatan konsentrasi sFlt-1 berkaitan dengan preeklamsia. Oleh karena itu, dibandingkan rerata, perubahan konsentrasi sFlt-1 lebih penting. Terdapat korelasi positif antara konsentrasi HIF-1 $\alpha$ dan sFlt-1 .

KATA KUNCI: sFlt-1, HIF-1 $\alpha$, preeklamsia, normotensi

\section{Indones Biomed J. 2013; 5(2): 121-8}

\section{Introduction}

Preeclampsia is a worldwide problem linked with maternal and fetal mortality or morbidity. The incidence of preeclampsia is approximately 1.8 to $16.7 \%$ of pregnancies, with the numbers varying between countries.(1) Based on data of the World Health Organizations by a systematic review of cases all over the world, $16 \%$ of maternal deaths in developed countries, including the United States, are due to hypertension in pregnancy and its complications. This figure outnumbers the figures of other major causes such as bleeding $13 \%$, abortion $8 \%$ and sepsis $2 \%$.(2)

In addition to the several dominant risk factors, a number of theories have been developed related to pathomechanism of preeclampsia, e.g. gene, immunity, oxidative stress, inflammation, hypoxia, angiogenic imbalance and hormone. Although most of the theories explain the initial problem of trophoblasts invasion, but until now they have not been able to produce a concept that can give a thoroughly satisfactory answer, due to the seemingly very complex interactions between one and the others.(3)

Lyall, et al., have shown a decline in vascular endothelial growth factor (VEGF) concentration in preeclampsia compared with that in normal pregnancy. VEGF level assessed in normal pregnant women was $12.89 \mathrm{pg} / \mathrm{mL}$, compared with VEGF level in women with preeclampsia of $2.34 \mathrm{pg} / \mathrm{mL}$. Decreased levels of VEGF in patients with preeclampsia was associated with increased soluble VEGF receptor released into the circulation, called soluble fms-like tyrosine kinase 1 (sFlt-1).(3)

sFlt-1 is a form of Flt-1 that has lost cytoplasmic and transmembrane domains but still has a ligand-binding domain. VEGF itself is a glycoprotein pro-angiogenic that works to increase proliferation, migration, and for survival of endothelial cells in increased capillary permeability. VEGF is a key signal used by the cells that are starved of oxygen (oxygen-hungry cells) to trigger the growth of blood vessels.(4)

Hypoxia inducible factor-1 (HIF-1) is an important element used in the regulation of transcription of various genes that appear in conditions with low oxygen level.(5) The etiology of the increased level of sFlt-1 is not clearly known until now, but it is suspected that hypoxia may contribute to the increase of this anti-angiogenic factor.

The objective of this study was to assess the dynamic mechanism of sFlt-1 as an anti-angiogenic factor and HIF$1 \alpha$ as hypoxia marker in normotensive and preeclamptic groups in mid-term and full-term pregnancy.

\section{Methods}

\section{Study Design, Subject Selection and Sample Collection}

A cohort study was carried out during the year of 20122013 on 36 normotensive pregnant subjects. First examination was conducted at mid-term pregnacy, 20-28 weeks gestation. Second examination was conducted at the time when preeclampsia was diagnosed or at full-term pregnancy if subjects remained normotensive. Multiple pregnancies and pregnancies with other complications were not included in this study. Our study was approved with ethical clearance number DM.01.04/11.3/229/2012 from the Ethical Committee of Prof. Kandou Hospital. Informed consents were obtained from all patients who were involved in this study.

Preeclampsia was characterized by hypertension with two readings, separated by 4-6 hours period, with systolic blood pressure $(\mathrm{SBP}) \geq 140 \mathrm{mmHg}$, diastolic blood pressure (DBP) $\geq 90 \mathrm{mmHg}$, and/or proteinuria by urine dipstick of $\geq 1+$ or $\geq 300 \mathrm{mg}$ per 24 hours after 20 weeks gestation. 
Table 1. Characteristics of subjects.

\begin{tabular}{|c|c|c|c|c|c|}
\hline \multirow{2}{*}{\multicolumn{2}{|c|}{ Characteristics }} & \multicolumn{2}{|c|}{ Group } & \multirow{2}{*}{$\begin{array}{l}\text { Total } \\
(\mathrm{n}=36)\end{array}$} & \multirow[b]{2}{*}{$p$ value } \\
\hline & & $\begin{array}{c}\text { Normotension } \\
\quad(n=27)\end{array}$ & $\begin{array}{c}\text { Preeclampsia } \\
(\mathrm{n}=9)\end{array}$ & & \\
\hline \multirow[t]{3}{*}{ Age } & inger ( $<20$ years) & 4 & 0 & 4 & $p=0.005$ \\
\hline & luctive (20-34 years) & 23 & 6 & 29 & \\
\hline & ler (>34 years) & 0 & 3 & 3 & \\
\hline \multirow[t]{2}{*}{ Gravidity } & Nulliparity & 17 & 3 & 20 & $p=0.123$ \\
\hline & Multiparity & 10 & 6 & 16 & \\
\hline \multirow[t]{2}{*}{ Parity } & None & 19 & 3 & 22 & $p=0.058$ \\
\hline & $\geq 1$ & 8 & 6 & 14 & \\
\hline \multirow[t]{2}{*}{ History of abortion } & None & 24 & 8 & 32 & $p=0.745$ \\
\hline & $\geq 1$ & 3 & 1 & 4 & \\
\hline \multirow[t]{3}{*}{ Smoking habit } & None & 5 & 0 & 5 & $p=0.214$ \\
\hline & Active & 0 & 0 & 0 & \\
\hline & Passive & 22 & 9 & 31 & \\
\hline
\end{tabular}

Table 2. Results of first and second examinations in normotensive group.

\begin{tabular}{lccccc}
\hline \multirow{2}{*}{ Variable } & \multicolumn{2}{c}{$1^{\text {st }}$ examination $(\mathrm{n}=27)$} & \multicolumn{2}{c}{$2^{\text {nd }}$ examination $(\mathrm{n}=27)$} & $p$ value* \\
& Median & Min - Max & Median & Min - Max & \\
\hline sFlt-1 $(\mathrm{pg} / \mathrm{mL})$ & $1,505.800$ & $360-5,394$ & $2,966.600$ & $1,342-16,798$ & $\boldsymbol{p}=\mathbf{0 . 0 0 0}$ \\
HIF-1 $\alpha(\mathrm{ng} / \mathrm{mL})$ & 2.370 & $0.200-21.600$ & 3.890 & $0.300-30.800$ & $p=0.648$ \\
GA (week) & 25 & $20-28$ & 36 & $34-39$ & $\boldsymbol{p}=\mathbf{0 . 0 0 0}$ \\
SBP (mmHg) & 110 & $100-130$ & 110 & $100-120$ & $\boldsymbol{p}=\mathbf{0 . 0 4 7}$ \\
DBP $(\mathrm{mmHg})$ & 70 & $60-80$ & 70 & $70-80$ & $p=0.083$ \\
sFlt-1 / GA & 60.510 & $13.300-192.600$ & 81.960 & $37.600-466.600$ & $\boldsymbol{p}=\mathbf{0 . 0 2 9}$ \\
HIF-1 $\alpha / \mathrm{GA}$ & 0.110 & $0.010-0.900$ & 0.110 & $0.010-0.790$ & $p=0.118$ \\
\hline
\end{tabular}

*Wilcoxon test, GA: gestational age, Min: minimum, Max: maximum.

Venous blood was drawn using a serum separator tube and allowed to clot for two hours at room temperature before centrifugation for 20 minutes at approximately $1,000 \mathrm{~g}$. Serum was immediately stored frozen in aliquots at $-20^{\circ} \mathrm{C}$ until assays for sFlt-1 and HIF-1 $\alpha$ were performed.

\section{Enzyme-linked Immunosorbent Assay (ELISA)}

For both sFlt-1 and HIF-1 $\alpha$ detections, ELISA method was performed. Quantikine ELISA Human sVEGF R1/Flt-1 Immunoassay (R\&D System, Inc., Minneapolis, MN) was used to detect sFlt-1. In principle, This assay employed the 
quantitative sandwich enzyme immunoassay technique. A monoclonal antibody specific for sFlt-1 was pre-coated onto a microplate. Standards and samples were pipetted into the wells and any sFlt-1 present was bound by the immobilized antibody. After washing away any unbound substances, an enzyme-linked polyclonal antibody specific for sFlt-1 was added to the wells. Following a wash to remove any unbound antibody-enzyme reagent, a substrate solution was added to the wells and color developed in proportion to the amount of sFlt-1 bound in the initial step. The color development was stopped and the intensity of the color was measured.

For HIF-1 $\alpha$ detection, HIF-1 $\alpha$ (Human) ELISA Kit (Abnova, Taipei, Taiwan) was used. Principally, the microtiter plate provided in this kit has been pre-coated with an antibody specific to HIF-1 $\alpha$. Standards or samples are then added to the appropriate microtiter plate wells with a biotin-conjugated polyclonal antibody preparation specific

Table 3. Results of first and second examinations in preeclamptic group.

\begin{tabular}{lccccc}
\hline \multirow{2}{*}{ Variable } & \multicolumn{2}{c}{$1^{\text {st }}$ examination $(\mathrm{n}=9)$} & \multicolumn{2}{c}{$2^{\text {nd }}$ examination $(\mathrm{n}=9)$} & $p$ value* \\
& Median & Min - Max & Median & Min - Max & \\
\hline sFlt-1 (pg/mL) & 993.200 & $433-2184$ & 3007.200 & $1473-6242$ & $\boldsymbol{p}=\mathbf{0 . 0 0 8}$ \\
HIF-1 $\alpha(\mathrm{ng} / \mathrm{mL})$ & 3.400 & $0.000-15.300$ & 4.930 & $0.200-17.600$ & $p=0.110$ \\
GA (week) & 25.000 & $20-27$ & 36.000 & $30-40$ & $\boldsymbol{p}=\mathbf{0 . 0 0 8}$ \\
SBP (mmHg) & 120.000 & $100-130$ & 140.000 & $140-160$ & $\boldsymbol{p}=\mathbf{0 . 0 0 7}$ \\
DBP $(\mathrm{mmHg})$ & 70.000 & $60-80$ & 90.000 & $90-110$ & $\boldsymbol{p}=\mathbf{0 . 0 0 7}$ \\
sFlt-1 / GA & 35.890 & $18.000-80.900$ & 100.240 & $37.400-178.300$ & $\boldsymbol{p}=\mathbf{0 . 0 1 5}$ \\
HIF-1 $\alpha /$ GA & 0.130 & $0.000-0.760$ & 0.140 & $0.010-0.450$ & $p=0.953$ \\
\hline
\end{tabular}

*Wilcoxon test, GA: gestational age, Min: minimum, Max: maximum.

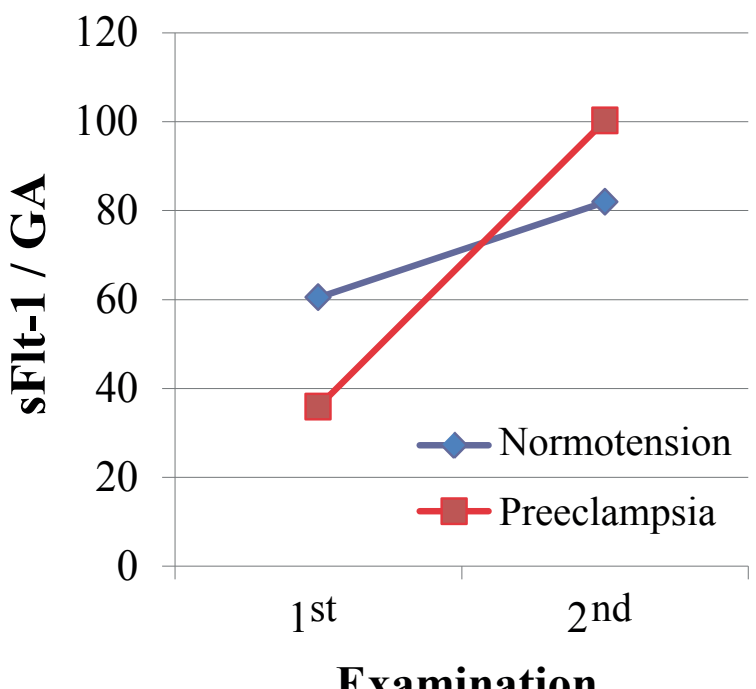

Figure 1. Changes of sFIt-1/GA ratio. GA: gestational age.

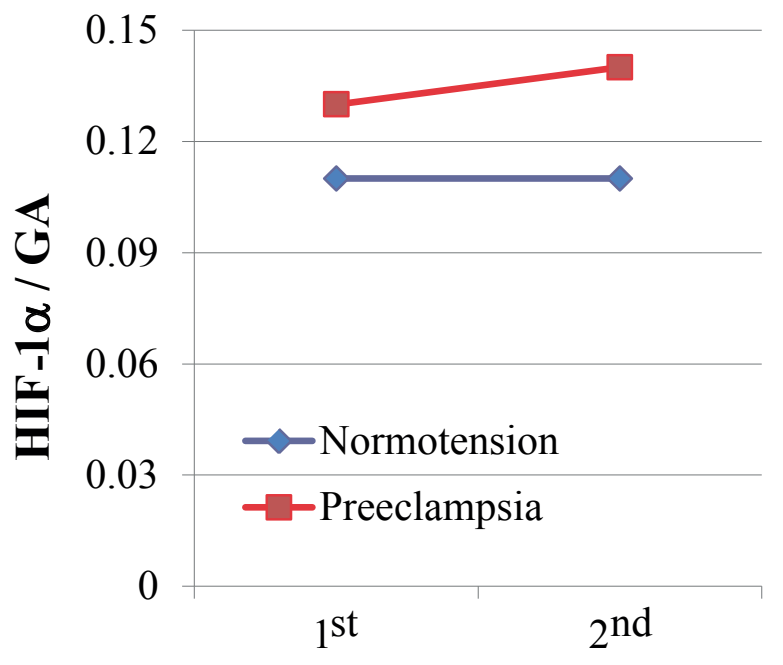

Examination 
Table 4. Analyses of HIF-1 $/$ /GA and sFlt-/GA ratios in preeclamptic group.

\begin{tabular}{cccc}
\hline \multicolumn{2}{c}{ Partial correlation between variables } & $\begin{array}{c}\text { Correlation } \\
\text { Coefficient }\end{array}$ & $\boldsymbol{p}$ value* \\
\hline $\begin{array}{c}1^{\text {st }} \text { examination } \\
\text { (mid-term pregnancy) }\end{array}$ & HIF-1 $\alpha$ vs. sFlt-1 & $\mathrm{r}=-0.022$ & $p=0.451$ \\
& HIF-1 $\alpha / \mathrm{GA}$ vs. sFlt-1/GA & $\mathrm{r}=0.001$ & $p=0.498$ \\
$2^{\text {nd }}$ examination & HIF-1 $\alpha$ vs. sFlt-1 & $\mathrm{r}=0.240$ & $p=0.082$ \\
(full-term pregnancy) & HIF-1 $\alpha / \mathrm{GA}$ vs. sFlt-1/GA & $\mathrm{r}=0.245$ & $p=0.078$ \\
\hline
\end{tabular}

*partial correlation test. GA: gestational age.

for HIF- $1 \alpha$ and Avidin conjugated to horseradish peroxidase (HRP) is added to each microplate well and incubated. Then a 3,3',5,5'-tetramethylbenzidine (TMB) substrate solution is added to each well. Only those wells that contain HIF-1 $\alpha$, biotin-conjugated antibody and enzyme-conjugated Avidin will exhibit a change in color. The enzyme-substrate reaction is terminated by the addition of a sulphuric acid solution and the color change is measured spectrophotometrically.

\section{Statistical Analysis}

Statistical analysis was conducted using SPSS version 11.5 (IBM Corp., Armonk, NY), with significance level set at $p<0.05$.

\section{Results}

The number of subjects involved at the first examination was 110 , but only 40 subjects remained at the second examination. Among 40 subjects, only 36 subjects were eligible for complete laboratory assessment (Table 1). From 36 subjects, with 2 examinations (middle-term or 2028 weeks gestation and at full-term pregnancies) for each subject, we collected 72 blood samples. All samples were processed and tested succesfully for sFlt-1 and HIF-1 $\alpha$ concentrations (Table 2\&3).

Table 1 shows that there was no significant differences in the characteristics regarding gravidity, parity, abortion history, and smoking habit between normotensive and preeclamptic groups. Both groups comprised more subjects at the prime reproductive age, nulliparity, no history of abortion and passive smokers. None of the younger group developed to preeclampsia, while all subjects in the older group developed to preeclampsia. Statistical analysis showed significant difference.

Differences of sFlt-1 and HIF-1 $\alpha$ concentrations according to gestational age (GA) were observed in normotensive and preeclamptic groups. Analyses of HIF$1 \alpha$ and sFlt- 1 concentrations changes at first and second examinations for normotensive (Table 2) and preeclamptic (Table 3) groups are shown. There were significant elevation of sFlt-1 and ratio of sFlt-1/GA from first to second examinations for both normotensive and preeclamptic groups. However, no significant changes of HIF-1 $\alpha$ and ratio of HIF- $1 \alpha / \mathrm{GA}$ from first to second examinations for both normotensive and preeclamptic groups. SBP showed significant inclination for both normotensive and preeclamptic groups from first to second examinations. Meanwhile DBP increased significantly for preeclamptic group from first to second examinations.

Figure 1 shows increase of sFlt-1/GA ratio for both normotensive and preeclamptic groups from first to second examinations. Despite the fact that at first examination, sFlt1/GA ratio was higher in normotensive than preeclamptic groups, sFlt-1/GA ratio of preeclamptic group was later increased steeply and reached higher ratio than the one of normotensive group at second examination.

Figure 2 shows a slight increase of HIF- $1 \alpha /$ GA ratio in preeclamptic group from first to second examinations, 
meanwhile no increase of the ratio was observed in normotensive group. HIF- $1 \alpha / \mathrm{GA}$ ratio were observed higher in preeclamptic than normotensive groups at first and second examinations. Table 4 shows no significant correlation between concentrations of HIF-1 $\alpha$ and sFlt-1, and also between ratios of HIF- $1 \alpha / \mathrm{GA}$ and sFlt-1/GA, either at the first or second examinations.

\section{Discussion}

We found a significant increase of preeclamptic risk as related to age. Preeclamptic group was found to be dominated by maternal age 35 years and above. CondeAgudello, et al., found that the relative risk of maternal age $\geq 35$ years was 1.67 (95\% CI 1.58-1.77).(6) Another report shows the largest number of primipara with preeclampsia is in category from 20 years $(p<0.01)$. Meanwhile for the multipara, preeclampsia is most commonly developed in age between 31-35 years.(7)

Increased preeclamptic risk in younger subjects with nulliparity was not found in this study, likely due to limited number of the sample size. Rudra, et al., stated that increase of preeclamptic risk in multiparity seemed to be related to hypoxia at the maternal-fetal surface.(8)

To observe the changes of sFlt-1 and HIF-1 $\alpha$, a cohort-time series observation was designed. When only normotensive group were observed (Table 2), it turned out that sFlt-1 concentrations and sFlt-1/GA ratios were increased significantly. This suggests that during pregnancy, sFlt-1 could increase normally along with GA. It was reported that in normotensive pregnancy, the concentration of sFlt-1 is considered stable until 2 months before the end of pregnancy when it may show increased concentration. (9) On the other hand, we also found significant increase of sFlt- 1 concentrations and sFlt-1/GA ratios in the group that developed preeclampsia (Table 3). It has been shown that increased concentration of sFlt-1 in subjects who developed preeclampsia seemed to be obvious at the second trimester, although placental growth factor (PlGF) and VEGF might have started to crash at the end of the first trimester.(9)

According to Romero, et al., in patients who develop preeclampsia during pre-term and full-term pregnancy, sFlt-1 levels were significantly higher that can be seen at 7 weeks, or even 11 weeks before the clinical diagnosis.(10) The changes of sFlt- 1 concentrations in normotensive and preeclamptic groups were shown in Figure 2. Although at first examination, sFlt-1/GA ratio was higher in normotensive than preeclamptic groups, sFlt-1/GA ratio of preeclamptic group was later increased steeply and reached higher ratio than the one of normotensive group at second examination. Park, et al., compared the concentration of sFlt-1 in normal pregnancy, mild preeclampsia, and severe preeclampsia. The results showed that in normal pregnancy, median: 441 $\mathrm{pg} / \mathrm{mL}$, range: $58-1,959 \mathrm{pg} / \mathrm{mL}$, mean $\pm \mathrm{SD}: 531 \pm 371 \mathrm{pg} / \mathrm{mL}$; mild preeclampsia, median: $334 \mathrm{pg} / \mathrm{mL}$, range: 60-3,375 $\mathrm{pg} / \mathrm{mL}$, mean $\pm \mathrm{SD}: 750 \pm 908 \mathrm{pg} / \mathrm{mL}$; severe preeclampsia, median: $762 \mathrm{pg} / \mathrm{mL}$, range 261-3,309 pg/mL, mean \pm SD: $962 \pm 688 \mathrm{pg} / \mathrm{mL}$. Median of sFlt-1 concentration was higher, although not significantly $(p=0.07)$ in severe preeclampsia compared with mild preeclampsia, while no significant differences were seen also between sFlt-1 concentration in mild preeclampsia and those in normotensive patients ( $p=0.84)$.(11) This finding can be explained due to results in this cohort study that almost all study subjects developed into mild preeclampsia. This is in contrast to the study result of Chaiworapongsa, et al., who found that an increase of sFlt-1 was correlated with disease severity.(12)

According to Lam, et al., preeclampsia does not develop in all women with high sFlt-1 or low PlGF, but can also occur in women with lower sFlt-1 and higher PlGF with not yet explainable mechanism. It was suspected that the enhancement of "soluble" factor occurred due to placental hypoxia. These findings were similar to our current results showing that sFlt-1 concentration in preeclamptic group were lower than sFlt-1 level in normotensive group.(4) Thomas, et al., suggested the possible involvement of sFlt-1 variants that significantly increased in preeclamptic subjects compared with normotensive subjects.(13)

In the normotensive pregnancies (Table 2), the HIF$1 \alpha$ concentration and HIF- $1 \alpha /$ GA ratio did not change significantly. These results suggested that in normotensive subjects, no hypoxic conditions were resulted that might endanger the mothers and fetuses.

sFlt-1 concentrations were lower at first examination and later became higher at the second examination which showed that sFlt-1 concentration at first examination could not be used as a reference for the possibility of preeclampsia.

A number of studies also showed no differences were found between the groups of normotensive and mild preeclampsia in mid-term. This suggests that elevated concentration of sFlt-1, in addition to the onset, also seem to be related to severity of preeclampsia, therefore the increase was slower. The study of Unal, et al., showed that in severe preeclampsia sFlt-1, the level might not show changes in 
the second trimester.(14) Similar results were also obtained in the study of Perni, et al., where at 20 weeks GA, sFlt1 concentration of normotensive group were in the range of $2,076 \pm 2,452.1$, while in the group with late-onset preeclampsia, were in the range of $1,426.6 \pm 1,132.2 .(15)$

According to Levine, et al., the average (mean) concentrations of sFlt-1 increased approximately 5 weeks before the onset of preeclampsia. This study did not observed sFlt-1 concentration increase up to the age of 29 weeks GA in subjects who subsequently developed to preeclampsia. At the time of clinical onset, mean concentration of sFlt1 was approximately 4,382 pg/mL.(16) Haggerty, et al., also concluded that the changes i.e. increase of sFlt-1 in the second trimester was associated with $39 \%$ increased risk of preeclampsia $(95 \%, \mathrm{CI}=3 \%, 86 \%) .(17)$

In our current results of HIF-1 $\alpha$ concentration and HIF-1 $\alpha /$ GA ratio, no significant difference between normotensive and preeclamptic groups was observed at both first and second examinations. This is probably due to another marker that precedes the other markers especially sFlt-1. Markers in fluctuating circulating levels or those that exist in a long period cannot be equated with the condition in the placenta. Peng, et al., examined the expression of HIF-1 $\alpha$ in placental bed and found the highest expression was in severe preeclampsia followed by mild preeclampsia. (18) According to Olyeymanlou, et al., HIF-1 $\alpha$ seems to induce s-Flt1 in placental explants.(19) Furthermore Tal, et al., stated that over-expression of HIF-1 $\alpha$ raised s-Flt1 and soluble endoglin (s-Eng) level and eventually led to the manifestation of preeclampsia, namely hypertension and proteinuria.(20)

Akhiles, et al., found that concentration of HIF-1 $\alpha$ in prenatal blood samples in preeclampsia were higher than those in postnatal period. Mean percentage reduction of HIF- $1 \alpha$ concentration in subjects from pre- to post-natal in preeclampsia reached $42.81 \%$.(21)

\section{Conclusion}

In this study higher concentration of sFlt-1 were found in preeclampsia. Changes in the levels of sFlt-1 were more important than the average levels. Even the changes of HIF$1 \alpha$ level were greater in preeclamptic group, but it have not been proven as an established circulating marker of hypoxia for preeclampsia. HIF-1 $\alpha$ levels tended to be positively correlated with sFlt-1.

\section{References}

1.Osungbade KO, Ige OK. Public Health Perspectives of Preeclampsia in Developing Countries: Implication for Health System Strengthening. J Pregnancy. 2011: 48109.

2.Khan KS, Wojdyla D, Say L, Gülmezoglu AM, Van Look PF. WHO analysis of causes of maternal death: A systematic review. Lancet. 2006; 367: 1066-74.

3.Lyall F, Bellfort M. Pre-eclampsia: etiology and clinical practice. Cambridge University Press: United Kingdom. 2007.

4.Lam C, Lim KH, Karumanchi SA. Circulating Angiogenic Factors in the Pathogenesis and Prediction of Preeclampsia. Hypertension. 2005; 46: 1077-85.

5.Zagorska A, Dulak J. HIF-1: the known and unknown of hypoxia sensing. Acta Biochim Pol. 2004; 51: 563-78.

6.Conde-Agudelo A, Belizan JM. Risk factors for pre-eclampsia in a large cohort of Latin American and Caribbean women. Br J Obstet Gynecol. 2000; 107: 75-83.

7.Jasovic-Siveska E, Jasovic V, Stoilova S. Previous pregnancy history, parity, maternal age and risk of pregnancy induced hypertension. Bratisl Lek Listy. 2011; 112: 188-91.

8.Rudra CB, Williams MA, Schiff MA, Koenig JQ, Dills R, Yu J. A prospective study of maternal carboxyhemoglobin and preeclampsia risk. Paediatr Perinat Epidemiol. 2010; 24: 35-44.

9.Grill S, Rusterholz C, Zanetti-Dällenbach R, Tercanli S, Holzgreve W, Hahn S, et al. Potential markers of preeklamsi-a review. Reprod Biol Endocrinol. 2009; 7: 70.

10.Romero R, Nien JK, Espinoza J, Todem M, Fu W, Chung H, et al. A longitudinal study of angiogenic (placental growth factor) and antiangiogenic $13(+6)$ weeks of gestation. Prenat Diagn. 2008; 28: $1110-5$.

11.Park CW, Park JS, Shim SS, Jun JK, Yoon BH, Romero R. An elevated maternal plasma, but not amniotic fluid, soluble fms-like tyrosine kinase-1 (sFlt-1) at the time of mid-trimester genetic amniocentesis is a risk factor for preeclampsia. Am J Obstet Gynecol. 2005; 193: 984-9.

12.Chaiworapongsa T, Romero R, Espinoza, J, Bujold E, Kim Y M, Goncalves LF, et al. Evidence supporting a role for blockade of the vascular endothelial growth factor system in the pathophysiology of preeclampsia. Am J Obstet Gynecol. 2004; 190: 1541-7.

13.Thomas CP, Andrews JI, Raikwar NS, Kelley EA, Herse F, Dechend $\mathrm{R}$, et al. A Recently Evolved Novel Trophoblast-Enriched Secreted Form of fms-Like Tyrosine Kinase-1 Variant Is Up-Regulated in Hypoxia and Preeclampsia. J Clin Endocrinol Metab. 2009; 94: 2524-30.

14.Unal ER, Robinson CJ, Johnson DD, Chang EY. Second-trimester angiogenic factors as biomarkers for future-onset preeclampsia. Am J Obstet Gynecol. 2007; 197: 2111-4.

15.Perni U, Sison C, Sharma V, Helseth G, Hawfield A, Suthanthiran M, et al. Angiogenic factors in superimposed preeclampsia: a longitudinal study of women with chronic hypertension during pregnancy. Hypertens. 2012; 59: 740-6.

16.Levine RJ, Maynard SE, Qian C, Lim KH, England LJ, Yu KF, et al. Circulating Angiogenic Factors and the Risk of Preeclampsia. N Engl J Med. 2004; 350: 672-83.

17.Haggerty CL, Seifert ME, Tang G, Olsen J, Bass DC, Karumanchi SA, et al. Second trimester anti-angiogenic proteins and preeclampsia. Pregnancy Hypertens. 2012; 2: 158-63.

18.Peng M, Ding Y, Yu L, Zhou C. Change of HIF-1 $\alpha$ protein expression in 
the placenta bed and concentration of vWF in maternal peripheral blood of pre-eclampsia. J Central South Univ (medical science). 2010; 35: 134-9.

19.Soleymanlou N, Jurisica I, Nevo O, Ietta F, Zhang X, Zamudio S, et al. Molecular Evidence of Placental Hypoxia in Preeclampsia. J Clin Endocrinol Metab. 2005; 90: 4299-308.

20.Tal R, Shaish A, Barshack I, Polak-Charcon S, Afek A, Volkov A, et al. Effects of hypoxia-inducible factor-1alpha overexpression in pregnant mice: possible implications for preeclampsia and intrauterine growth restriction. Am J Pathol. 2010; 177: 2950-62.

21.Akhilesh M, Mahalingam V, Nalliah S, Ali RM, Ganesalingam M, Haleagrahara N. Hypoxia-inducible factor-1a as a predictive marker in pre-eclampsia. Biomed Reports. 2013; 1: 257-8. 